\title{
INVENTORY AND REGENERATION POTENTIAL OF BROWNFIELDS ALONG THE D1/A1 MOTORWAY OSTRAVA (CZ) - GLIWICE (PL)
}

\author{
Jaromír KOLEJKA ${ }^{1}$, Jan ŠTRBÍK ${ }^{1}$, Renata DULIAS ${ }^{2}$
}

DOI: 10.21163/GT_2017.122.11

\begin{abstract}
:
The paper presents the procedure of assessing the redevelopment potential of brownfields within the $10 \mathrm{~km}$ wide zone along the D1/A1 motorway Ostrava - Gliwice". In the first part, the basic ideas and terms of the issue are explained. The second part has a methodological character where methods used to determine and assess the redevelopment potential of the brownfields are described and applied on examples in the study territory. The field data collection was supported by the application of the Google Maps Street View technology. The paper outputs in the third part are based on presented working methods in GIS and represented with the brownfields assessed for the purpose of their future best usage.
\end{abstract}

Key-words: brownfields, utility potential, new highway, Upper Silesia, Czech Silesia, Street View, GIS

\section{INTRODUCTION}

The issue of brownfields is among the most frequent themes discussed in both the professional and journalistic practice in most developed countries,. The term "brownfields" comes from the English literature and is used in it its original form for its uniqueness in this subject in the Czech language even without translation. In the Czech terminology, however, other terms such as "depressing zones" or "disturbed land" are commonly used at the governmental level (Kadeř́bková et al. 2009). In the world literature, this term is widely discussed and there are many definitions available. Brownfield land is primarily the result of deindustrialization and suburbanization (USA) (see Alker et al. 2000). In the English definition, brownfields include previously developed land - with or without any level of contamination - that is currently unused or underused (Longo\& Campbell, 2016). Certain skepticism is expressed by Jackson et al. (2004) who state that brownfields are land, disused or underused with negative consequences not only of an ecological character. In the Czech Republic, a brownfield is seen as a territory of former industrial uses, which can include industrial buildings and areas, logistic zones, ravaged built-up land, but also residential or commercial buildings in the urbanised area. These include also other abandoned military, agricultural and non-functional built-up areas in the landscape (Opatová, 2008). Rydvaldová \& Žižka (2006) perceive brownfields as old sites and disused facilities, locations or objects located both in urbanised areas, as well as in the open areas. They represent areas and buildings previously used for some form of economic activity in the past. Also in Poland there are also a number of definitions used in different legislative

I Masaryk University, Department of Geography, CZ-60300, Brno, Czech Republic, jkolejka@centrum.cz.

${ }^{2}$ University of Silesia, Department of Geography, PL-41-200, Sosnowiec, Poland, renata.dulias@us.edu.pl 
documents. The Polish Ministry of Regional Development (2011) states: brownfields are "Areas designated for reclamation, they include degraded or ruined properties, such as closed landfills, junkyard, former industrial areas, former mining areas, and former military lands on which the authorities have approved reclamation."

There is a wide range of options and criteria to classify brownfields available here. A common distribution of brownfields by their origin is based on their use in the past. Such locations are marked by both their historical development and their occurrence. Nový et al. (2004) classify brownfields by (1) the original use into abandoned industrial buildings; energy, mining, storage, agricultural buildings, transport and military constructions; degraded parts of towns, and dilapidated buildings with historical value. The governmental agency Czech Invest notes that although the brownfields were mainly mentioned in connection with the transformational changes in the industry, the largest number of brownfields are of agricultural origin and the industry is on second place is in the Czech Republic. However, from the viewpoint of the size, significantly originally industrial brownfields occupy the largest area in the Czech Republic. Another brownfield subdivision may be based on (2) the position (in built-up areas of towns, in suburban zones, in outskirts of villages and small communities, outside any urban area). (3) The size of brownfields is one of the leading factors not only in abroad (e.g. in France, UK, etc.), but also in the Czech Republic. It indicates namely the attractiveness of the location, along with its accessibility (pedestrian, by rail/road). The higher investment comes with the larger size and therefore large areas often remain unused. Agency Czech Invest supports the development of brownfield areas up 10 ha only (Nový et al, 2004). Based on (4) the ecological burden, brownfields can be distinguished as areas with uncertain environmental disturbance; areas without demonstrated environmental disturbance; brownfields with anticipated environmental loads; and brownfields with existing environmental loads (Šilhánová et al., 2006). Based on (5) the new possibilities for use Šilhánová et al. (2006) divides brownfield lands as follows: a) Capable of finding a new use in the context of market mechanisms (for a private or public developer or for cooperation between the two); b) where the assistance of public funds has to be found for the new usage (public developer or cooperation between the public and private sector);and c) where a new usage can not be found and the area must be reclaimed.

The reasons, why brownfields originated in the past, depend mainly on their type of brownfields. The main cause of origin of most brownfields lies primarily in the economic transformation primarily. It is associated with a change in the contribution share of sectors in the gross domestic product (Grulich, \& Gargoš, 2009). The significant change in the structure of the economy was due to the transfer of labour power, usually from the primary sector with the predominant raw material extraction, agriculture as well as forestry and fisheries, and then into the secondary sector, i.e. industry, manufacturing and construction. Later, however, this transfer of labour power continued into the tertiary sector, which includes trade, services and public sphere. The processes that led to such changes were first recorded in Western Europe in the 1970s.

In the Czech Republic, these changes have occurred until the early 1990s with the change of the political and economic situation from a centrally planned to a market economy. There are also other reasons that led to the emergence of brownfields, such as:

1. Loss of the attractiveness of the site (perhaps in connection with a change in the ethnic composition of the local population - this led to the origin of residential brownfields).

2. Demilitarization after the collapse of the bipolar world - army brownfields originated (barracks, contaminated military areas). 
3. Changes in the agricultural subsidy policy and self-organization of farmers - agricultural brownfields originated (property of numerous former agricultural cooperatives, abandoned buildings and land).

4. Technological change and the decline of interest in some raw materials - brownfields originated as a relic of discontinued mining.

5. Some brownfields arose from a simple lack of interest of their owners and an unwillingness to resolve their status, e.g. route change of communication arteries to another location within the modernization of road and railway networks (service brownfields transport, trade, catering, etc.).

Consequences that come from the existence of brownfields are mostly strongly negative. There area near the brownfields becomes less attractive and the total value of the land is also reduced. Some economic, social and environmental impacts aggregate and particularly with them the unemployment rate also rises. Finally, there is a negative emotional impact on people, which contributes to the displacement of the territory.

The original land use of the site can cause environmental problems that exist in a given area and may deepen day by day. Environmental loads now usually represent usually the most costly problem in brownfields regeneration and often also make often also a barrier to its re-use. However, the loads must be removed before re-using to avoid endangering human health and the environment.

Brownfield regeneration has affected all industrialized countries since the late 1960s. Brownfields constitute a serious problem for the development of municipalities, cities and regions. The issue of recovery has become a key priority in many strategies, whether at the national, regional or local levels. However, investors are commonly not interested in sites on contaminated territory or in dilapidated buildings (see Williams \& Dair, 2007).

The main barriers to the implementation of the recovery are (Conroy \& Berke, 2004; Adams et al. 2001; De Sousa, 2000; Dvořáková \& Lišková, 2010; Černík, Kunc, Martinát, 2016):

- complicated ownership in brownfield sites

- construction on greenfields is a cheaper and simpler solution

- environmental loads and high costs of their removal

- lack of data for better knowledge and understanding of brownfields and prioritizing existing and/or new development programmes

- little experience with brownfield regeneration

- unused possibilities of cooperation between the public and private sectors

- few incentives for private investors

- the original brownfield purpose and its consequences

- lack of the public interests

Regardless of the above mentioned experience, the main driving forces in the brownfield regeneration are the Ministry of the Environment (Ministerstvo životního prostředí, 2004), the Ministry of Industry and Trade (Ministerstvo průmyslu a obchodu, 2008) and CzechInvest - Investment and Business Development Agency (CzechInvest Agentura pro podporu podnikání a investic, 2008) and:

- state-run specialized agencies and institutions - ministries (through programmes and strategies)

- specialized agencies and institutions focusing on environmental issues

- local and regional authorities 
- financial institutions and insurance companies

- technical consultants

- private owners

- real estate experts

- developers and investors

- public and civic associations

All these have to be provided with a sound data basis for decision making. While locals feature the necessary location and historical information or the general idea of the condition of the land, most expert information is rare and sources differ according to previous studies on this issue.

Two basic access groups to study the issue of brownfields can be distinguished which may well to follow each other (by Novosák et al. 2013):

1. Spatial analysis of brownfields. This includes inventory, mapping and classification of brownfields in a particular territory

2. Evaluation of identified brownfields for needs of their future development and use. Such studies are based on multi-objective methods with various ways of assessing criteria and with various aggregation abilities of partial assessments to reach the total final evaluation.

Well-known brownfield studies differ in terms of the details of the studies (Svobodová \& Věžník, 2009; Novosák et al. 2013; Klusáček et al. 2013 - some additions):

1. regional - dealing with a relatively large area and thus providing quantitative and qualitative inventory data especially useful for higher administration levels of the state from the national territory to the industrial regions of continental dimensions

2. metropolitan (agglomeration) - dealing with urbanized centres and their peripheries, or with their rural vicinity inclusively

3. local - in urban centres, industrial parks, individual areas outside town and cities

\section{IDENTIFICATION OF BROWNFIELDS DEVELOPMENT POTENTIAL}

The incorporation of the evaluation results of brownfield usability into the concept of the future status of the territory is subject both to territorial and landscape planning (Vaníček, in Nepomuk \& Salašová, 1996). The planning in the territory as a human activity generally follows the objective of further adapting the environment to the needs of human housing, work and relaxation. The decision-making on a particular area's future is based on scientific knowledge and on determining the territory's "potential."

Generally, the potential of a territory is defined as "the ability of the territory to provide a number of options and assumptions for various applications to meet the needs of human society. These options and assumptions are applicable to the production of material goods, their circulation, consumption and reproduction, recreation of humans and on fitting human needs in general" (Haase, in Drdoš, 1979). These also include the cultural, scientific, social and aesthetic needs. Besides the term "potential" (Sheppard, 1979), the term "land suitability" is well known and commonly used in the Anglo-Saxon literature, with equal meaning and content (e. g. Coward \& Heywood, 1992; Jarvis \& MacDonald, 1993). The term "ecological potential" is also widely used in recent Russian literature (Isačenko, 1995). The issue of the territorial or landscape potential is also covered with extensive literature indicating the great importance of this subject for addressing the current needs of the society to sustainable landscape development. 
Individual land properties affect specific human activities in different ways. This is due to the fact that each type of land usage requires well defined land parameters, or combinations of these parameters. In many cases, certain values of the land features of the relevant area exclude some human activities.

The natural conditions of the territory serving relevant human activity or purpose represent the basis for determining the natural landscape potential (Haase, 1978; Gringmuth, 1979). In practice, this means that a purposeful parameter evaluation of the natural landscape structure can obtain information about scalable, spatially differentiated area suitability for a particular function. The natural potential of the territory is determined either for a particular activity or a range of activities such as "sector (specific) landscape potential" (see Drdoš, 1979; Sporbeck 1979; Drgoňa 1981; Lehotský, 1981; Power \& Paynter, 1993) or comprehensively to a set of monitored activities such as the "total landscape of potential" (Kolejka, 1981) in the form of relevant sector potentials. If necessary, their aggregation is possible (Weichhart \&Weingartner 1983; Batelková, Kolejka \& Pokorný, 1996). In the case of brownfields, a territory is intensely changed as a rule by humans where only some of the natural features of the site may apply in deciding the area's future fate (e. g. slope aspect - a location for photovoltaic panels to regenerate the site, topographic position - alluvial plain - flood protection). However, in the case of brownfields, the main issue is the redevelopment potential, i. e. the possibility of future use of a site already intensively used in the past (Doležalová et al. 2014).

The general methodological basis of the determination of redevelopment potential is based on the principle purpose-oriented analysis of the properties of the relevant area, and on the synthesis of the partial findings. The identification of comprehensive redevelopment potential of the area follows the principles of determining the optimal use of the brownfield land in accordance with the current state of knowledge, the topic features of the territory, communication/transportation and socio-economic situation. The aim is to ensure the site's sustainable development, especially the economic sustainable development which has to meet the current needs of society so that future generations can meet their needs as well. The determination of the redevelopment potential of the area thus means finding opportunities to meet the needs of the site, without the production area being exhausted, damaged, destroyed or restricted. In fact, the research aim is to discover a reconciliation between the features of the territory and its future use. This does not mean that all the relevant potential of the area will be used for the targeted specific human activities (see Drdoš \& Ot'ahel', 2007). However, it is obvious that its share will gradually decline in urbanized centres and their peripheries, as it is shown by present experience.

Any potential determining is always a process of multi-criteria evaluation of relevant area properties. Therefore, the following is generally recommended for assessment (Drdoš, in Izakovičová, Miklós \& Drdoš, 1997):

1. Completing a database on the elements of the assessed areas, with particular regard to the parameters that affect the potential to be determined, dynamic processes and interactions.

2. Input data on claims of monitored human activities for which the potential of the area will be determined,

3. Inclusion of data on the sensitivity of the local environment on a particular activity.

4. Respecting the activity's impact on the environment and on other activities (especially with regard to reciprocity of conflicts). 
Because of the traditional human preference for selected area properties, an comprehensive functional evaluation must rely on suitability evaluation of all relevant properties. The evaluation process must respect certain general principles:

1. The assessment goal must be as precisely defined because each assessment is purposeful.

2. The evaluation criteria must be determined, e. g. only selected relevant area parameters will be applied (see Kaufman, Murray \&Rogers, 2003; Page \& Berger, 2006).

3. The rating scale must be established.

4. The method of partial evaluations agglomeration must be determined when multiparameter evaluation is necessary (e. g. remediation score - by Eden, 2016).

5. The method of presenting results must be defined.

The result of a comprehensive or total functional assessment area which is based on a representative set of the properties of all the relevant factors, may be: A) a specific value of the partial potential - measured for selected human activity, or B) the total potential of an area, presented by the sequence of individual partial potentials, by an integral value obtained by aggregating the values of the partial potentials.

The determination of the total potential of the area (for the full set of monitored human activities) may be a problematic issue, because many activities have conflicting demands on local conditions. The values can vary a lot. The value of a potential in that area can be very high on one site, and very low on another site. Another problem is the role of a conflict. It is quite common, that many functions are mutually exclusive for implementation on the same plane, although this area may be favourable for them. Choosing the best of them can be quite subjective. It can vary depending on time and the intentions of users under the influence of a number of internal and external circumstances. Therefore, it is necessary to approach the full landscape potential with great caution.

The brownfields potential assessment model drawn up by the German Ministry of Environment was inspired by Rydvalová \& Žižka (2006). This evaluation model is based on defining 28 criteria, which are divided into three groups (a site's potential in terms of community, the potential of the benefits in terms of investors and potential in terms of public interest). Furthermore, the model compares the possibility of construction on a greenfield and a reuse of a brownfield. The criteria for site potential and benefit potential are evaluated on a five-point scale from 0 to 4 points, where 4 points represents the highest obtained value. The potential from the perspective of public interest is evaluated on a scale of -2 to +2 points, wherein the two points are the highest value obtained. Moreover, all the criteria are attributed a certain degree of importance.

The Ostrava-Katowice industrial area is a region in which the issue of brownfields is very significant (Novosák \& Bednář, 2011; Kunc, Klusáček \& Martinát, 2011; Vojvodíková, 2013; Martinát et al. 2015; Krzysztofik et al. 2016). One possible development potential assessment approach was been used in practice on a sample area of the Ostrava area in 2011. This approach works with these factors: the physical location within the spatial structure of the model area, the social status of the local population, the area size, the density of buildings in the area, the complexity of ownership structure, the site position in relation to the transport network, the location environmental load, the duration of abandonment, and the previous dominant use (Novosák \&Bednár, 2011).

The Regional Development Agency of the South Moravia Region used the procedure to evaluate the potential of brownfields on the region's model territory where the individual 
parameters (indicators) are assigned a score (min. 0 - max. 10 points, differently in each criteria category). The index is represented by available data on individual brownfields and relevant municipalities where these cadastral areas objects belong. Groups of indicators consist of various individual indicators. The final scoring is assigned according to the predefined rating scale (Hladik, 2010).

Kolejka (2013) assessed the territory potential for landscape planning purposes. This author evaluated selected territory parameters in a four-stage scale (0-3 points) to determine the potential value of the area. The evaluated parameters are e. g. the slope of the terrain, the soil type, the rocks, the local climate, etc. The mathematic operation "sum" aggregated the results of the partial evaluations. The summarized evaluation results in five variables ranging from 0 (the lowest possible value) to a maximum of 15 points, which were divided into five classes.

The individual potential classes were displayed on the map. Although this methodology was used to apply the identification of the potential outside urbanized areas, it can also be applicable for the brownfield regeneration potential assessment (see below).

\section{DEFINITION AND CHARACTERISTICS OF THE STUDY AREA}

The paper deals with the assessment and the significance of the regeneration potential of abandoned sites along the international motorway connecting the cities Ostrava in the Czech Republic (in the South) and Gliwice in Poland (in the North)- the cities in the industrial and settlement agglomerations. The Czech D1 motorway connects to the Polish A1 at the border. The motorway is a part of the international European route E75. The study area is located on the territory of two countries. It is located in the administrative unit the Moravian-Silesian Region (Miravsko-slezský kraj in Czech) in the Czech Republic and in the administrative unit the Silesian Voivodship (Polish Województwo Śląskie) in Poland. It connects two parts of the Upper Silesian Coal Basin. It covers an area of approximately $7000 \mathrm{~km}^{2}$, of which Czech territory extends over an area of approximately $1600 \mathrm{~km}^{2}$. In both national segments of the Upper-Silesian Coal Basin, industry is still a dominant activity: especially coal mining and metallurgy has occupied considerable importance in the past and in the present as well. The development of industry, coal mining, agriculture and the overall socio-economic history are almost identical in the two neighbouring segments in the last hundred years as well as their consequences in the subsequent formation of brownfields. The coal mining in the Upper Silesian Basin began in 1657 (south of Katowice), but the actual development of the mining industry, both in the Czech and Polish parts of the basin, occured in the second half of the 19th century. During World War II the study territory was occupied by Nazi Germany (the westernmost part of the basin belonged to pre-war Germany). After the end of World War II the communist regime came to power in both countries, which was associated with strong industrialization and nationalization. The black coal production gradually increased until it peaked in 1979. Since 1988, it has been steadily declining. After the fall of the communist regime in the late 1980s, a return to a market economy and restructuring of traditional industries carried out in both countries. This is the period when the issue of brownfields (about 20 years later than in the United States and Western Europe) received considerable in both countries for the first time. The causes of this development are very similar in Poland and the Czech Republic, as well as in other post-communist countries of Central Europe. It can be summed up in a single point: the weak economic profitability of coal mining. In Poland, unlike in the Czech Republic, the interference of unprofitable mines went slower due to the higher social status of Polish 
miners and high coal consumption for Polish power plants. In 2004, both countries joined the European Union, which implies an analogous access to EU development funds and subsidies.

During the 1990s both governments adopted reforms that resulted in the phasing out of mines with the lowest return. In the southern segment of the Polish part of the basin some mines are still being expanded and the deeper lying layers of coal are being reached. Black coal mining has a negative impact as a heavy load on the landscape and on the environment. The terrain has been formed mainly by heaps and subsidences. The case of the church of St. Peter of Alcantara in Karviná serves as an example. Its vertical axis is inclined by 6.8 degrees. The surrounding terrain has fallen almost 36 metres. It is important to eliminate or at least to reduce the impact of mining consequences on the landscape according to current legislation by the land reclamation. Coal mining resulted also positively with the origin of countless biologicallyvaluable sites, for example wetlands and lakes. They were later resettled with native animal and plant species originally displaced from the territory occupied by humans. Also heaps (consisting of millions of tons of dredging spoils) became a significant part of the landscape in some places, for example they tend to be a tourist destination (Katedra geografie Př́rodovědecké fakulty UP v Olomouci, 2012).

Average monthly gross wage per capita was 23487 CZK (Czech crowns) in the Moravian-Silesian region in mid-2010s, which is the sixth highest salary in comparison with other regions of the country. The unemployment rate was $8.3 \%$ on October 31,2015 (according to data from the Czech Statistical Office). The coal basin area is densely populated (981 inhabitants per square $\mathrm{km}$ ). Two-thirds of the population live in cities with over 20,000 inhabitants. There is highly developed industrial production in comparison with other regions of the Czech Republic. The main industrial center of the region is the City of Ostrava. Coal mining, metallurgical and energy industries are still dominant in the region's industry. Other important industries are machinery (e. g. car assembly), electronics, food, chemical and pharmaceutical and textile.

The population density in the neighboring Silesian voivodship is 372 inhabitants per square $\mathrm{km}$, which is the highest value in Poland. The most densely populated area is the central Gliwice-Katowice conurbation with more than 1,000 inhabitants per $\mathrm{km}^{2}$. The region is also heavily urbanized; $78 \%$ of the population live in cities. The main economic sectors include services and industry. Coal mining and metallurgy dominate in industry followed by energy production, machinery, automobile and chemical industries (Główny Urząd Statystyczny, 2014a). The average monthly wage per capita in the $3^{\text {rd }}$ quarter of 2013 amounted to 4002.29 PZL, which in comparison with other regions of Poland is the second highest salary. At the end of August 2014, the unemployment rate was 9.9\% (Główny Urząd Statystyczny, 2014b).

\section{DATA}

The necessary data collection for the study area was conducted both in the field and by the archived data search on brownfields. With respect to the size of the study area ( 840 $\mathrm{km}^{2}$ ), a number of field campaigns were required. The study territory was represented with a belt of land with a width of $10 \mathrm{~km}(2 \times 5 \mathrm{~km}$, on the both sides of the road) along over 82 $\mathrm{km}$ of motorway. The research was divided into several stages. In 2013 it was carried out a thorough mapping of the Czech section of the D1 motorway and the half section of the A1 from the international border to the Polish inland. The survey was carried out by J. Kolejka, 
A. Ruda, H. Svobodová and H. Svatoňová. The data assembly along the Polish section was performed by R. Dulias. The final reconnaissance and additional field research was done with revisions by J. Strbík in 2014 and 2015. This way, the inventory of abandoned sites along the D1/A1 motorway was completed (D1 from the intersection with the first class national road no. 11) in Czech Republicto Gliwice (the road intersection the A1 with the national road No. 88, the former pre-war German motorway) in Poland to a width of $5 \mathrm{~km}$ on either side of the highway. The A1 motorway zone has attracted development interest for some years (Hibszer, 2013).

The laboratory preparationpreceded the field brownfield inventory. Using Google Maps and the Street View application, potential brownfields objects and areas were preliminarily identified. With the help of aerial photographs and satellite images from Google Maps, objects of a larger area, especially heaps after underground mining, were selected as well as tailing ponds or large abandoned industrial or agricultural areas. Using Street View, which contains panoramic images (this service offers panoramic pictures of streets), other areas or preliminarily ("roughly") identified areaswere clarified. Outside cities panoramic landscapes pictures from the same source were also used, as the landscape can be seen from the road. These images were taken directly by driving a car at a height of about 2.5 metres, with a frequency of one image about every 10 meters of distance traveled (Google, 2015). This way, theindividual objects and smaller areas located in the cities and beyond them were primarilyselected for the visit. Residential buildings, former shopping and business centers, and other buildings that formerly served as civic services were registered. Other objects and areas were also included in the database provided they could be seen in these images beside the road. This way, larger objects were also checked if displayed in the image. In some cases, a clarification was not possible because these objects were found away from the road and/orwere covered with an obstacle, building and/or tall vegetation. Since Google regularly updates its data, the identificationof potential brownfield objects was very accurate usingthis method. The vast majority of the buildings actually matched the display images. Neither aerial or satellite images of the study area were older than one year. Only panoramic images were a maximum 3 years old.

The preparatory phase was followed by planning a reconnaissance route. Above all, saving time and mileage was an important point. The website Mapy.cz and specifically its application route planner were used to plan a route. The route was always planned separately for each phase of the field inventory.

Several facts were recorded for each object and area. The first one was their previous or original use. For some objects it was obvious at first sight, for what purpose they served in the past they served. If it was not obvious, this information was detected on the internet from sources where such use could be mentioned. Furthermore, the research benefited from the Land Registry. Passers-by were also interviewed, by asking them if they knew what the object or area served for in the past. If any information was stated it was subsequently verified on the internet and only then taken into account.

Another phenomenon that was investigated was the environmental pollution. The objects or areas were first personally visited and visually investigated to see whether there were any oil stains or spots after fuel fluids. Attention was also focused to see if there were any signs of storage of hazardous substances.

Furthermore, the share of the built-up area of the brownfieldterritorywas preliminarily estimated. The share of the built-up area was always checked during subsequent laboratory ground data processing over current aerial photographs, and also according to the Land 
Registry, where the studied parcels are registered as built-up areas or as courtyards. The size of the object was measured accurately in ArcMap.

The final data set comprised 20revised previously identified sites, 63 of which have been investigated recently. A total of 31 buildings were examined in the Czech Republic, and a total of 52 on the territory of Poland. These objects and areas were classified according to their original use into a total of 16 types (Tab. 1).

Table 1

Genetic classification of detected brownfields along the D1 /A1 motorway in 2015

\begin{tabular}{|l|r|l|r|}
\hline category & number & category & number \\
\hline brick industry & 1 & residential & 9 \\
\hline devastated area & 4 & industrial ponds & 3 \\
\hline metallurgy & 4 & not identified & 6 \\
\hline chemical industry & 3 & waste dump & 1 \\
\hline coking industry & 1 & machinery & 3 \\
\hline distillery industry & 1 & mining & 24 \\
\hline furniture industry & 2 & agricultural buildings & 13 \\
\hline trade and services & 5 & railway station & 3 \\
\hline
\end{tabular}

Source: own research

Registered individual objects or areas are very diverse in their size. The largest site has an area of 236 ha it is a heap after coal mining. Conversely, the smallest object has an area of only $97 \mathrm{~m}^{2}$, it was the remnant of a metallurgical furnace. A total of 6 areas are larger than 100 ha, all of which are heaps after coal mining. The size of a total of 21 areas ranges between 10-100 hectares. It includes mainly heaps after coal mining again, but also some large areas previously used by the chemical, metallurgical and brick industries, and also two tailing ponds. A total of 30 areas have a smaller size of between 1-10 ha. Agricultural buildings are primarily within this range. A total of 27 objects have an area of 0-1 ha. Within this range are mostly objects that were previously used for residential functions, trade and/or services.

\section{METHODS}

The data processing was performed in ESRI GIS ArcMap version 10.3.1. Because most of the study territory is located in Poland, the data processing was performed in the coordinate system Pulkovo 1942 Adj 1958 Poland Zone I. The base map was compiled from the available orthophotos from both the countries. The Czech Republic was representedby the orthophoto of the Czech national INSPIRE Geoportal. The territory of Poland was documented by the orthophoto of the Polish National INSPIRE Geoportal. Both the orthophotos were connected using WMS.The vectorization of the areas identified by the field research, including the line of the motorway and $10 \mathrm{~km}(2 \times 5 \mathrm{~km})$ wide zone along it was overlaid above them. The northern and southern edges of the strip are determined by the local roads. The GIS tool Buffer was used for the representation and the demarcation of the study area. 
The GIS tools were applied directly to measure the distance of the monitored objects/areas from the motorway, as well as to measure the size of the objects/areas. A table was created for each object or area with their parameters and their evaluation. A total of 7 potential human activities were consideredfor the brownfields regeneration: (1) logistics (2) shopping center, (3) car parking, (4) residential construction, (5) afforestation, (6) industrial production and (7) recreation and the suitability of each brownfield was determined for each activity.

The final brownfield regeneration potential was represented by the results of the integration of partial evaluation of the nine factors:

(1) The origin of the brownfield:

The original purpose served by the object or the area.

(2) The size (ha):

The area of the object and/or the area. It was measured in ArcGIS.

(3) The distance directly from the motorway (in metres):

The linear distance of the object or the area from the highway. This value was measured in ArcGIS.

(4) The distance from the nearest motorway exit (in metres):

The actual distance of the object or the area from the nearest highway exit. This value was measured using the Mapy.cz route planner tool.

(5) The driving distance to the motorway (in minutes):

This value indicates the amount of time in minutes that the journey will take from the object or the area to the nearest motorway exit. This value was also measured using the Mapy.cz route planner tool.

(6) The direct distance from the nearest city center (in metres):

It is the linear distance from the object or the area to the nearest town center. Here only towns with populations greater than 20,000 inhabitats have been taken into account. This line lenght was measured using the Google Earth tool to measure the distance.

(7) The built-up rate (in \%):

It represents the percentage of the total area of the site that is built up. It was estimated directlyduring the field investigations, and subsequently checked and completed both by the topic aerial imagery and by the insight into the cadastre to look for which areas are either designated as buildings or as courtyards.

(8) The area shape:

The specific shape value $(R e)$ was calculated according to the formula (1). The resulting value describes the "longity" of the complex compared to the circle.

$$
\operatorname{Re}=\frac{\sqrt[2]{\frac{P}{\pi}}}{L v}
$$

(9) The environmental load:

All the brownfields were assessed according to the "load level". This factor was defined by Novosák \&Bednár (2011). The identified brownfields were divided into three groups. The first group includes objects and areas that were originally used for agriculture, trade and services, furniture industry and for residential buildings. The authors of this contribution added railway brownfields into this group, because in all cases they are represented by disused former railway station buildings only in smaller communities. A higher environmental load is therefore not assumed and during the field investigation no signs of 
environmental pollution were there. The list od brownfields also includes other brownfield classes, where no ecological impact is expected and it was not found even in the field survey (e. g. collapsed residential buildings). The second group by (Novosák \&Bednár, 2011) included brownfields originally used for coal mining. The third group included objects or areas originally used for the metallurgy, chemical, engineering and coke industries. The fourth group with the largest environmental load included tailings ponds.

The suitability of each factor (of the 9 possible) for a specific activity (of the 7 possible) was evaluated on a scale of 0-3 points with 0 - indicating that the site is unsuitable for the intended purpose, 1 - less suitable, 2 - medium suitable, and 3 - very suitable.

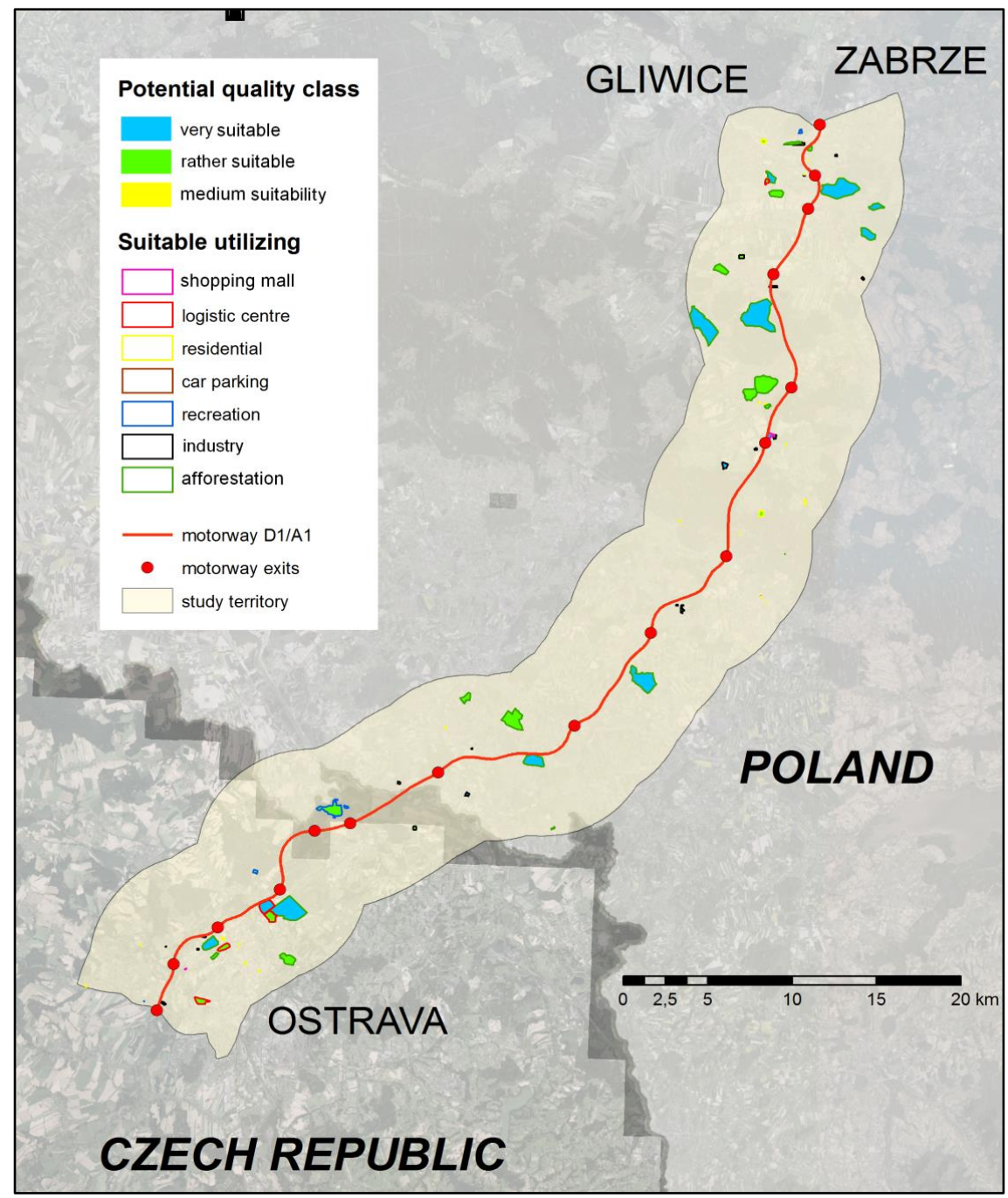

Fig. 1 The first brownfields regeneration potentials for the whole study territory along the D1/A1 motorway (Source: own processing, satellite images INSPIRE portals). 
Each combination (pair) of the factor and the considered potential activity (future application) was evaluated and a score table was prepared and applied to each identified brownfield. This evaluation was carried out in the most simple form, so that the same procedure could be reproduced by any researcher in the future, and/or those interested in a particular location. This means that individual factors were assigned the same weight, or importance, although the authors had sophisticated procedures available which can differentiate individual factors according to their importance in the assessment procedure. The potential human activities assessed for the brownfields regeneration were orderedinto a sequence accorfing to their social-ecological significance (Tab. 2). Table 3 serves as an example of the relationship between the importance of potential human activity and the brownfields origin during the assessnent.

\section{Preferences of monitored potential activities (potential future use) (example)}

\section{Table 2}

\begin{tabular}{|l|l|l|l|}
\hline order & activity & $\begin{array}{l}\text { cartographicpresentation } \\
\text { - color }\end{array}$ & justification \\
\hline 1 & afforestation/park & dark green & $\begin{array}{l}\text { A heavily industrialized area with a } \\
\text { damaged environment requires the } \\
\text { creation of an oasis of calm with a } \\
\text { positive effect on the surroundings. }\end{array}$ \\
\hline 2 & recreation & dark blue & $\begin{array}{l}\text { It serves to regenerate the health of the } \\
\text { population by offering active rest. }\end{array}$ \\
\hline 3 & $\begin{array}{l}\text { residential } \\
\text { construction }\end{array}$ & yellow & $\begin{array}{l}\text { It replaces the old industrial dwelling with } \\
\text { higher quality and will attract, resp. keep } \\
\text { people in the region in the expected } \\
\text { deindustrialisation process. }\end{array}$ \\
\hline 4 & shopping mall & purple & $\begin{array}{l}\text { It represents a supply of public services to } \\
\text { a broad circle of inhabitants and, at the } \\
\text { same time, a certain number of jobs. }\end{array}$ \\
\hline 5 & industry & black & $\begin{array}{l}\text { It represents a higher number of jobs in } \\
\text { the realization of an environmentally } \\
\text { acceptable industrial activity. }\end{array}$ \\
\hline 7 & car parking & brown & $\begin{array}{l}\text { It represents a supply of a certain number } \\
\text { of jobs, but with a certain risk of traffic } \\
\text { noise increasing and certain difficulties } \\
\text { associated with the increase in traffic } \\
\text { intensity. }\end{array}$ \\
\hline
\end{tabular}

Source: own research 
Table 3

Brownfields origin assessment from the viewpoint of the convertion possibility into the potential use (example)

\begin{tabular}{|c|c|c|c|c|c|c|c|}
\hline activity & logistics & industry & shopping mall & residential & car & afforestation & rekreation \\
\hline origin & & & & & & & \\
\hline rail transport & 1 & 1 & 1 & 0 & 1 & 1 & 0 \\
\hline agricultural area & 2 & 3 & 2 & 2 & 2 & 1 & 1 \\
\hline machinery & 2 & 2 & 1 & 1 & 2 & 1 & 1 \\
\hline waste dump & 0 & 0 & 0 & 0 & 2 & 2 & 0 \\
\hline mining & 0 & 0 & 0 & 0 & 0 & 3 & 2 \\
\hline other & 2 & 2 & 2 & 2 & 2 & 2 & 2 \\
\hline industrial ponds & 2 & 2 & 1 & 0 & 2 & 2 & 0 \\
\hline residential & 1 & 1 & 1 & 3 & 1 & 1 & 1 \\
\hline trade and eervices & 2 & 2 & 3 & 2 & 1 & 1 & 2 \\
\hline furniture industry & 2 & 3 & 2 & 2 & 2 & 1 & 2 \\
\hline distillery industry & 2 & 3 & 2 & 1 & 2 & 1 & 1 \\
\hline coking industry & 2 & 2 & 2 & 0 & 2 & 1 & 1 \\
\hline chemical industry & 2 & 2 & 2 & 0 & 2 & 1 & 1 \\
\hline metallurgy & 2 & 2 & 2 & 0 & 2 & 1 & 1 \\
\hline brick industry & 2 & 2 & 2 & 0 & 2 & 1 & 1 \\
\hline devastated area & 3 & 3 & 3 & 2 & 3 & 2 & 2 \\
\hline
\end{tabular}

Source: own research

An example of the purpose oriented factor evaluation to a specific activity is given in table 4.

Evaluation of the driving distance to the nearest motorway exit

Table 4 (for the shopping mall location in the brownfields area) (example)

\begin{tabular}{|l|c|}
\hline Driving distance [min.] & evaluation \\
\hline $0-3$ & 3 \\
\hline $4-6$ & 2 \\
\hline $7-19$ & 1 \\
\hline 11 and more & 0 \\
\hline
\end{tabular}

Source: own research 


\section{RESULTS AND EVALUATION}

Each identified brownfield was equipped with the sequence of 7 monitored regeneration potentials, i.e.with the value of the potential for each of the considered activities (for example the brownfield no. 18 in the table 5).

\section{Potentials of brownfields no. 18 (example)}

Table 5

\begin{tabular}{|c|c|c|c|c|c|c|c|c|}
\hline BF18 & activites & \multirow{2}{*}{ logistics } & \multirow{2}{*}{ industry } & \multirow{2}{*}{$\begin{array}{l}\text { shopping } \\
\text { mall }\end{array}$} & \multirow{2}{*}{$\begin{array}{l}\text { residential } \\
\text { construction }\end{array}$} & \multirow{2}{*}{$\begin{array}{c}\text { car } \\
\text { parking }\end{array}$} & \multirow{2}{*}{ afforestation } & \multirow{2}{*}{ recreation } \\
\hline \multicolumn{2}{|l|}{ factors } & & & & & & & \\
\hline origin & mining & 0 & 0 & 0 & 0 & 0 & 3 & 2 \\
\hline size (in ha) & 179,63 & 3 & 0 & 0 & 1 & 0 & 3 & 1 \\
\hline $\begin{array}{l}\text { distance from } \\
\text { motorway (in m) }\end{array}$ & 528 & 2 & 2 & 2 & 2 & 0 & 2 & 3 \\
\hline $\begin{array}{l}\text { distance from } \\
\text { motorway exit } \\
\text { (in m) }\end{array}$ & 4100 & 2 & 2 & 2 & 2 & 0 & 2 & 2 \\
\hline $\begin{array}{l}\text { driving distance } \\
\text { to the motorway } \\
\text { exit (in min.) }\end{array}$ & 6 & 2 & 2 & 2 & 2 & 0 & 2 & 2 \\
\hline $\begin{array}{l}\text { distance from } \\
\text { city center (in } \\
\text { m) }\end{array}$ & 3800 & 3 & 3 & 3 & 2 & 0 & 2 & 2 \\
\hline $\begin{array}{l}\text { rate of build-up } \\
\text { (in\%) }\end{array}$ & 0 & 3 & 3 & 3 & 3 & 3 & 3 & 3 \\
\hline $\begin{array}{l}\text { shape (in } \\
\text { coefficient } \\
\text { values) }\end{array}$ & 0,9 & 3 & 3 & 3 & 3 & 3 & 3 & 3 \\
\hline $\begin{array}{l}\text { ecological load } \\
\text { (in degrees of }\end{array}$ & 2 & 2 & 2 & 2 & 0 & 3 & 3 & 1 \\
\hline & $\sum=$ & 20 & 17 & 17 & 15 & 9 & 23 & 19 \\
\hline & $\begin{array}{c}\text { potential } \\
\text { order }\end{array}$ & $2^{\text {nd }}$ & $5^{\text {th }}$ & $4^{\text {th }}$ & $6^{\text {th }}$ & $7^{\text {th }}$ & $1^{\mathrm{st}}$ & $3^{\text {rd }}$ \\
\hline
\end{tabular}

Source: own research

The assessment scale used allows assigning 0 or 1 or 2 or 3 points to be assigned to the selected activity depending on brownfield features suitability (e.g. according to table 4). By using the sum as an aggregation method of partial evaluations, the individual activities (total of 7 possible) may obtain an overall minimum 0 of points and a maximum of 27 points (9 evaluated factors times maximum 3 points). In case of equality of scores for various activities, it was decided to prioritize the activities that are higher in the order of their socio-ecological importance (see tabel 2). 
According to the total scored points, the potential for each activity was included (see table 6) in a certain class of importance. This way, each brownfield was distinguished from each other by the preferred suitability for the particular activity (future use) according to its point gain. At the same time, the topicbrownfields suitability for a given activity was defined. Only the first three potentials of each brownfield were presented in the maps.

Table 6

Classes of brownfields regeneration potentials

\begin{tabular}{|l|c|c|c|c|c|}
\hline evaluation in points & $0-7$ & $8-12$ & $13-17$ & $18-22$ & $23-27$ \\
\hline area potential & unsuitable & $\begin{array}{c}\text { less } \\
\text { suitable }\end{array}$ & $\begin{array}{c}\text { medium } \\
\text { suitability }\end{array}$ & $\begin{array}{c}\text { rather } \\
\text { suitable }\end{array}$ & $\begin{array}{c}\text { very } \\
\text { suitable }\end{array}$ \\
\hline $\begin{array}{l}\text { cartographic presentation } \\
\text { - color }\end{array}$ & red & orange & yellow & green & blue \\
\hline
\end{tabular}

Source: Kolejka, 2013, modified

The map completion was performed according to the already published procedures (Kolejka, 2013). The full area color displays the class of the potential (5 classes from very suitable to unsuitable- see tabel 6), the contour (outline) color of the area then shows the most suitableactivity for the brownfields regeneration (the best future use). The outline color expresses cartographically the most appropriate future utilisation for a given class of the regeneration potential (see tab. 2): shopping center - purple, logistics - red, residential construction - yellow, car parking - brown,recreation - dark blue, afforestation - dark green, industry - black.

The final maps were generated in three resolutions in order to represent the smallestbrownfields and their best potential use. The map of the total study area corresponds to an original scale of 1: 300000 (Fig. 1). The partial motorway section maps were constructed to an original scale of 1: 100000 (Fig. 2) and local segments to an original scale of 1: 10000 (Fig. 3).

The level of the first regeneration potential was reached by 21 brownfields in the class „,very suitable“, the first potential of 52brownfieldswas in the class „,rather suitable“, and 11 brownfields reached their first potential in the class ,medium suitability“.

At the level of the second potential remain 5 brownfields in the class „,very suitable“, 44 brownfields have the second potential in the class „,rather suitable“, 34 brownfields have the second potential in the class „medium suitability“ and 1 brownfields fall in the second potential to the class ,less suitable“ for the regeneration by given activity.

Values of the third potential were achieved in the class ,very suitable“by 4 brownfields, by 39 brownfields in the class ,rather suitable“, by 39 brownfields in the class „medium suitability“, and by 2 brownfields in the class „less suitable“. These values can be applied very well in the decision on brownfields' future use within their regenerationforthe activity preferred by the given potential. The sequence of three most appropriate activities is known for each brownfields (see tab. 2 and 6) and each activity (the form of future use) is described with its level of suitability (bythe potential class).

The territtorial distribution of brownfieldsshows that most of them are concentrated close to large cities, especially within and around the big cities of Ostrava and Gliwice. 


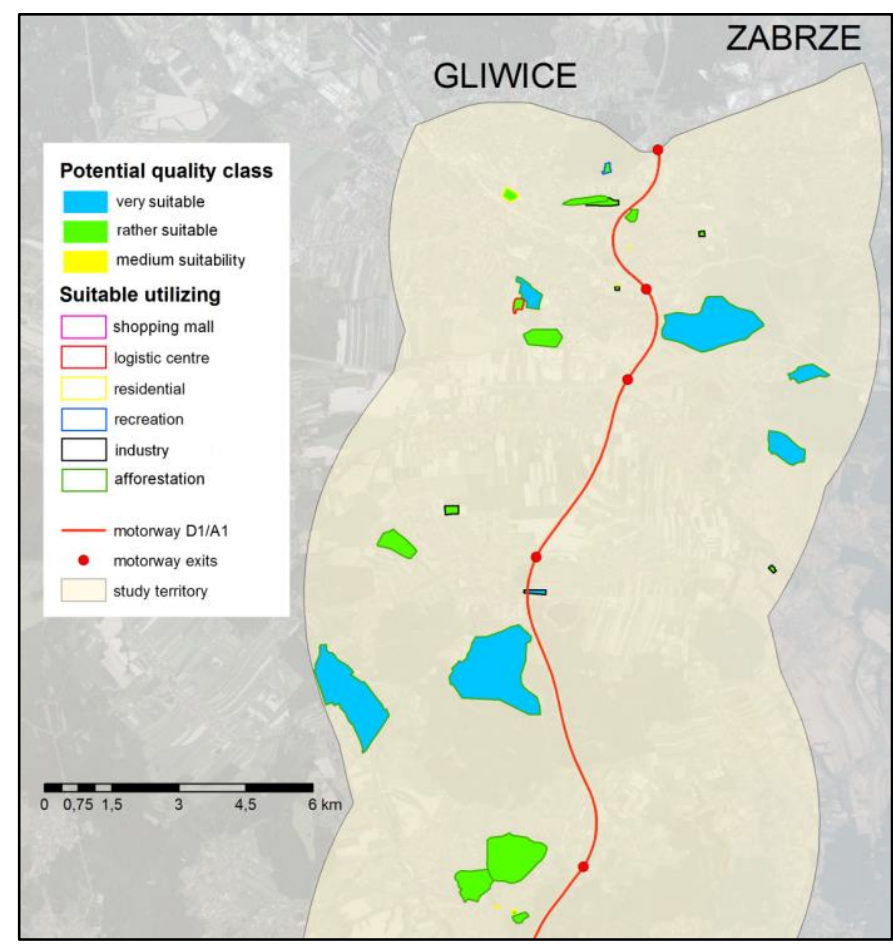

Fig. 2 Example of the map of the first brownfields regeneration potentials for the northern most part of the study territory along the D1/A1 motorway

(Source: own processing, staellite images INSPIRE portals).
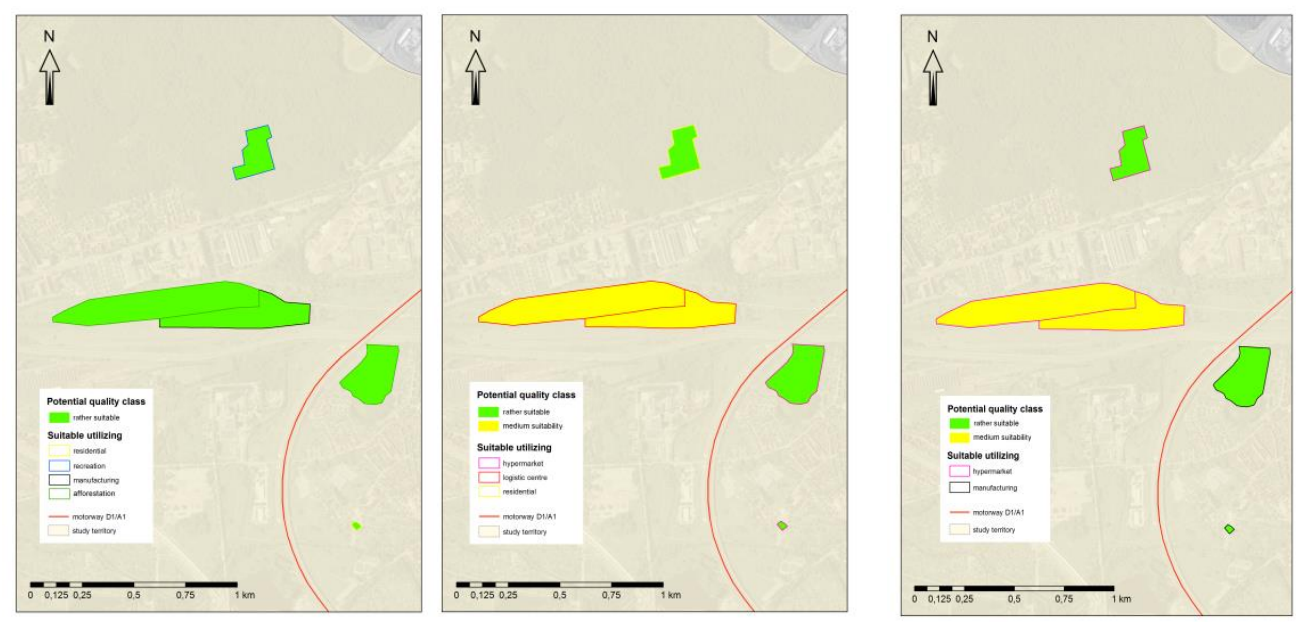

Fig. 3 Examples of the maps of the first, the second and the third brownfields regeneration potentials for the local segment of the study territory along the D1/A1 motorway near Gliwice (Source: own processing, staellite images INSPIRE portals). 


\section{CONCLUSION}

The finished survey shows that there are a large number of abandoned areas and buildings in the examined area of the $10 \mathrm{~km}$ wide strip along the international motorway D1/A1 from Ostrava to Gliwice. These sites lost their original usage; they are deteriorating and depressing their surroundings. However, there are also a large number of brownfields, which are now in a very lucrative zone for investors after completion of this section of the international motorway and they have a significant regeneration potential. Therefore their future use as e.g. logistic zones, industrial production resumption areas, shopping centers, parking lots for trucks, new housing and recreation areas can befound.

The researchresults can be used e. g. in municipalities, whose cadastral area these sites are locatedin. Each community should promote brownfields sites and attract investors to cooperate. The performed regeneration would mean getting rid of the negative effects that are associated with these sitesfor the community. An increase in economic activity, new jobs and other benefits resulting from brownfields redevelopment would, among other things,positively influence the lives of local people.

\section{ACKNOWLEDGMENTS}

This paper was compiled on the basis of research results taken during the grant project "Upper Silesian corridor - brownfields as development challenge“ No. 222333 supported by the Ministry of Foreign Affairs of the Czech Republic in the AB programme.

\section{R E F E R E N C E S}

Adams, D., Disberry, A., Hutchison, N., Munjoma, T., (2001). Ownership constraints to brownfield redevelopment. Environment and Planning A, 33 ( 3), 453-477.

Alker, S., Joy, V., Roberts, P., Smith, N., (2000). The Definition of Brownfield. Journal of Environmental Planning and Management, 43 (1), 49-69.

Batelková, K., Kolejka, J., Pokorný, J., (1996). Horňácko - krajinná syntéza a GIS při hodnocení př́rodní krajiny pro plánování regionálního rozvoje. Geografie - Sborník ČGS, 101 (4), 296309.

Conroy, M. M. \& Berke, P. R., (2004). What makes a good sustainable development plan? An analysis of factors that influence principles of sustainable development. Environment and Planning A, 36 ( 8), 1381-1396.

Coward, P. \& Heywood, I., (1992). Multiple Criteria Decision Analysis as a Method for Quality Assurance in GIS. In: Proceedings The Canadian Conference on GIS, EMR/CISM, Ottawa, pp. 643-653.

CzechInvest, Agentura pro podporu podnikání a investic. (2008). Základní statistické výsledky Vyhledávaci studie brownfieldi. [Online]. Available from: http://www.czechinvest.org/ data/files/nsb-595.pdf [Accessed 12 $2^{\text {th }}$ December 2014].

Černík J., Kunc J., Martinát S., (2016). Territorial-technical and socio-economic aspects of successful brownfield regeneration: a case study of the Liberec region (Czech Republic). Geographia Technica, 11 (2), pp. 22-38.

De Sousa, Ch., (2000). Brownfield Redevelopment versus Greenfield Development: A Private Sector Perspective on the Costs and Risks Associated with Brownfield Redevelopment in the Greater Toronto Area. Journal of Environmental Planning and Management, 43 (6), 831-853.

Doležalová, L., Hadlač, M., Kadlecová, M., Martinát, S., Polednik, M., (2014). Redevelopment potential of brownfields: a-b-c classification and its practical application. E+M. Ekonomie a Management = Economics and Management, (2), 34-44. 
Drdoš, J. \& Ot’ahel', J., (2007). Prínos fyzickej geografie k rozvoju krajinnej ekológie na Slovensku. Folia geographica, 46 (11), 110-116.

Drdoš, J., (1979).: Optimalizácia funkčnej štruktúry vidieckej krajiny na príklade Zvolenskej kotliny. In: Funkčná analýzy a metódy výskumu pretrvávajúcich sa agrárnych priestorov. Békéscsaba, pp. 29-53.

Drgoňa, V., (1981).: Hodnotenie krajiny z hl'adiska jej potenciálu pre pol’nohospodársku výrobu $\mathrm{v}$ novšej geografickej literatúre. Geografický časopis, 33 (2), 197-212.

Dvoř́ková-Lišková, Z., (2010). Správa k problematice brownfields. [Online]. Available from: http://ccv.ef.jcu.cz/opvkreg/prezentace/okruh7/pri7tema-09-Vnimani_problema tiky_brownfields_Li.pdf [Accessed $13^{\text {th }}$ October 2014].

Eden, E., (2016).: Real-Estate Site Locates Redevelopment Potential Across Philadelphia. [Online]. Available from: https://www.planetizen.com/node/86680/real-estate-site-locatesredevelopment-potential-across-philadelphia [Accessed 21 ${ }^{\text {st }}$ March 2017].

Główny Urząd Statystyczny. (2014a). Rocznik Statystyczny Przemystu 2013. [Online]. Available from: http://stat.gov.pl/obszary-tematyczne/roczniki-statystyczne/roczniki-statystyczne/rocznikstatystyczny-przemyslu-2013,5,7.html [Accessed $17^{\text {th }}$ September 2015].

Główny Urząd Statystyczny. (2014b). [Rocznik Statystyczny Województw 2013. Online]. Available from: http://stat.gov.pl/obszary-tematyczne/roczniki-statystyczne/roczniki-statystyczne/rocznikstatystyczny-wojewodztw-2013,4,8.html [Accessed 17 ${ }^{\text {th }}$ September 2015].

Google. (2015). Google Street View. [Online]. Available from: https://www.google.com/maps/ streetview/ [Accessed 10 June 2015].

Gringmuth, W., (1979). Zur ökonomischen Bedeutung von Naturpotentialen und Naturresourcen und $\mathrm{zu}$ den Bedingungen ihrer Nutzung und Reproduktion. Wissenschaftliche Abhandlungen der Geographischen Gesellschaft der DDR, (14), 41-48.

Grulich, T. \& Gargoš, I., (2009). Brownfieldy v České republice: Koncepční podpora regenerace agenturou Czechinvest. Urbanismus a územní rozvoj. 12 (6), 6-8.

Haase, G., (1978). Zur Ableitung und Kennzeichnung von Naturpotentialen. Petermanns Geographische Mitteilungen, 122, (2), 113-125.

Hibszer, A., (2013). Social investment conflicts related to the construction of the A1 motorway in the Silesian voivodeship (Southern Poland). Environmental \& Socio-economic Studies, 1(3), 35-44.

Hladík, J., (2010). Metoda hodnocení rozvojového potenciálu brownfields Regionální rozvojové agentury Jižní Moravy. Brno, Regionální rozvojová agentura Jižní Moravy.

Isačenko, A. G., (1995). Ekologičeskaja geografija Severo-Zapada Rossii. Část Part 1. SanktPeterburg, Russkoye geograficheskoye obshchestvo.

Izakovičová, Z., Miklós, L., Drdoš, J., (1997). Krajinnoekologické podmienky trvalo udržatel’ného rozvoja. Bratislava, Veda.

Jackson, J. B. et al., (2004). Brownfields snadno a rychle -Přriručka zejména pro pracovníky a zastupitele obcí. Praha, IURS.

Jarvis, I. \& MacDonald, K. B., (1993). Land use planning using a GIS to evaluate land suitability for agriculture. In: Proceedings The Canadiasn Conference on GIS, EMR/CIG, Ottawa, 550-560.

Kadeřábková, B., (2009). Brownfields: jak vznikají a co s nimi. Praha, C. H. Beck.

Katedra geografie Př́rodovědecké fakulty UP v Olomouci. (2012). 'Transformace těžby nerostných surovin. [Online]. Available from: http://geography.upol.cz/soubory/lide/ szczyrba/RGPOL/ucebnice/seg/transformace_tezby_nerostnych_surovin.html[Accessed $\quad 12^{\text {th }}$ September 2015].

Kaufman, M. M., Murray, K. S., Rogers. D. T., (2003). Surface and Subsurface Geologic Risk Factors to Ground Water Affecting Brownfield Redevelopment Potential. Journal of Environmental Quality, 32 (2), 490-499.

Klusáček, P., Krejčí, T., Martinát, S., Kunc, J., Osman, R., Frantál, B., (2013). Regeneration of agricultural brownfields in the Czech Republic - Case study of the South Moravian Region. Acta Universitatis Agriculturae et Silviculturae Mendelianae Brunensis, 21 (2), 549-561.

Kolejka, J., (1981). Aproximace elementárního potenciálu území. Zprávy Geografického ústavu ČSAV, 18 (4), 242-263. 
Kolejka, J., (2013) Nauka o krajině: Geografický pohled a východiska. Praha, Academia.

Krzysztofik, R., Tkocz, M., Sporna, T., Kantor-Pietraga, I., (2016). Some dilemmas of postindustrialism in a region of traditional industry: The case of the Katowice conurbation, Poland, Moravian Geographical Reports, 24 (1), 42-54.

Kunc, J., Klusáček, P., Martinát, S., (2011). Percepce a lokalizace urbánních brownfields: podobnosti a rozdíly na př́íkladu Brna a Ostravy, Urbanismus a územní rozvoj, 14 (1), 13-17.

Lehotský, M., (1981). Evaluácia krajiny z hl'adiska jej potenciálu pre pol’nohospodársku výrobu a prognóza jeho využitia. Geografický časopis, 33 (2), 180-196.

Longo, A. \& Campbell, D., (2016). The Determinants of Brownfields Redevelopment in England. Environmental and Resource Economics. [Online]. Available from: http://link.springer.com/article/10.1007/s10640-015-9985-y [Assessed 25 ${ }^{\text {th }}$ March 2017].

Martinát S., Kunc J., Klusáček P., Krejčí T., Navrátil J., Vnenková J., Černík J., (2015). Spatial relations and perception of brownfields in old industrial region: case study of Svinov (Ostrava, Czech Republic). Geographia Technica, 10 (2), pp. 66-77.

Ministerstvo průmyslu a obchodu. (2008). Národni strategie regenerace brownfieldi̊. Praha, MPO.

Ministerstvo životního prostředí. (2004). Strategie udržitelného rozvoje České republiky. [Online]. Availble from: http://www.mzp.cz/C1257458002F0DC7/cz/strategie_ udrzitelneho_rozvoje/ \$FI LE/KM-SUR_CR-20100114.pdf [Assessed 27 ${ }^{\text {th }}$ September 2014-9-27].

Nepomucký, P. \& Salašová, A., (1996). Krajinné plánování. Ostrava, Vysoká škola báňská.

Novosák, J. \& Bednář, P., (2011). Hodnocení rozvojových předpokladů brownfields. Žilina, Georg.

Novosák, J., Hájek, O., Nekolová, J., Bednář, P., (2013). Spatial Pattern of Brownfields and Characteristics of Redeveloped Sites in the Ostrava Metropolitan Area (Czech Republic). Moravian Geographical Reports, 21 (2), 36-45.

Nový, A., (2004). Brownfields - šance pro budoucnost. Brno, Fakulta VUT v Brně.

Opatová, Y., (2008). Brownfields-Greenfields-město: úloha zeleně při obnově devastovaných územi města. Brno, Vysoké učení technické.

Page, G. W. \& Berger, R. S., (2006). Characteristics and land use of contaminated brownfield properties in voluntary cleanup agreement programs. Land Use Policy, 23 (4), 551-559.

Polish Ministry of Regional Development. (2011). Rewitalizacja. Ministerstwo Rozwoja. [Online]. Available from: http://www.mir.gov.pl/strony/zadania/polityka-rozwoju-kraju/rewitalizacja/ [Accessed 10 $0^{\text {th }}$ June 2015].

Power, S. \& Paynter, J., (1993). The Use of GIS in Municipal Boundary Extension Analysis. In: Proceedings The Canadian Conference on GIS, EMR/CIG, Ottawa, pp. 498-510.

Rydvalová, P. \& Žižka, M., (2006). Ekonomické souvislosti revitalizace brownfields. [Online]. Available from: http://ndz.hf.tul.cz/download/2006/Ekonomicke_ souvislosti.pdf [Accessed $28^{\text {th }}$ April 2014].

Sheppard, E. S., (1979). Geographic Potentials. Annals of Association of American Geographers, 69 (3), 438-447.

Sporbeck, O., (1979). Bergbaubedingte Veränderungen des physischen Nutzungspotentials, Paderborn, Schöningh.

Svobodová, H. \& Věžník, A., (2009). To the problems of agricultural brownfields in the Czech Republic - case study of the Vysočina region. Agricultural Economics - Czech, 55 (11), 550 556.

Šilhánková, V. et al., (2006). Rekonverze vojenských brownfields. Pardubice, Univerzita Pardubice.Vnimani_problematiky_brownfields_Li.pdf [Accessed 13 ${ }^{\text {th }}$ October 2014].

Vojvodíková, B., (2013). Brownfieldy - cesta od minulosti do budoucnosti, Praha,European Science and Art Publishing.

Weichhart, P. \& Weingartner, H., (1983). : Preliminary considerations on the application of the potential concept to alpine regions (by example of the Tennengebirge, Salzburg, Austria). In: Drdoš, J. (edit.): Landscape Synthesis. Geoecological Foundations of the Complex Landscape Management. Bratislava, Veda, pp. 154-167.

Williams, K. \& Dair, C., (2007). A framework for assessing the sustainability of brownfield developments. Journal of Environmental Planning and Management, 50 (1), 23-40. 